\title{
Cannabis and amphetamine use and its psychosocial correlates among school-going adolescents in Ghana
}

Kwaku Oppong Asante $1,2,3^{*}$ (D)

\begin{abstract}
Background: The aim of this study was to examine the prevalence of cannabis and amphetamine use and to determine its associated factors among school-going adolescents in Ghana.

Method: The 2012 Ghanaian Global School-based Student Health Survey on 3632 adolescents aged 11-19 years ( mean $=15.1$ years; $S D=1.4$ ) was used. Participants for this study were sampled from selected junior (JHS) and senior high schools (SHS) in all the 10 administrative regions of Ghana. A two-stage cluster sampling design was used to select 25 senior high schools to represent all the 10 regions of Ghana. Information was collected with a self-administered structured questionnaire that contained information on demographics, alcohol, tobacco and other drug use, violence, and a range of other health-related behaviours.
\end{abstract}

Results: The result showed that past-month cannabis use was 5.3\% and lifetime amphetamine use was 7.1\% among students. In multivariate model, after controlling for other variables, school truancy and current cigarette smoking were associated with both past-month cannabis and lifetime amphetamine use. The number of close friends was associated with only past-month cannabis use. School environment factors (bullying victimisation and having been attacked) and parental substance use were associated with lifetime amphetamine use.

Conclusion: This study identified a number of risk factors, including parental substance use and various risk behaviours, for both past-month cannabis and lifetime amphetamine use. School-based health intervention programmes should be developed taking into consideration the risk factors associated with cannabis and amphetamine use among school-going adolescents.

Keywords: School-going adolescents, Amphetamine use, Cannabis use, Risk factors, Ghana

\section{Introduction}

Illicit drug use contributes significantly to the global burden of disease, and thus is considered an emerging public health problem $[1,2]$. According to the United Nations Office on Drugs and Crime (UNODC), the global prevalence of illicit drug use (including amphetamines, cannabis, cocaine, opioids, etc.) in 2015 was 5.3\% [3]. The same report also indicated that cannabis, amphetamine-type

\footnotetext{
*Correspondence: kwappong@gmail.com; koppongasante@ug.edu.gh ${ }^{1}$ Department of Psychology, University of Ghana, P. O. Box LG 84, Legon, Accra, Ghana

Full list of author information is available at the end of the article
}

stimulants, cocaine, and opioids were the most commonly used illicit drugs [3].

In a South African population-based survey conducted among individuals aged 12 years and older in 2012, past 3 -month prevalence of illicit drug use was 4.4\% [4]. A Ghanaian population-based national study conducted in 2008 among school-going adolescents, found the prevalence of past 1-month (any) drug use to be 3.6\% [5]. Earlier follow-up studies among adolescents in Ghana reported prevalence rates of $2.6 \%$ and $7.2 \%$ for pastmonth cannabis use $[6,7]$.

Previous studies have established that specific sociodemographic factors are associated with both cannabis and amphetamine use, including male gender $[5,8]$ and older

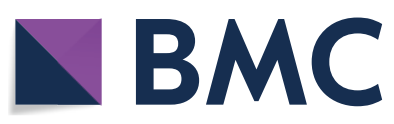

(c) The Author(s) 2019. This article is distributed under the terms of the Creative Commons Attribution 4.0 International License (http://creativecommons.org/licenses/by/4.0/), which permits unrestricted use, distribution, and reproduction in any medium, provided you give appropriate credit to the original author(s) and the source, provide a link to the Creative Commons license, and indicate if changes were made. The Creative Commons Public Domain Dedication waiver (http://creativecommons.org/ publicdomain/zero/1.0/) applies to the data made available in this article, unless otherwise stated. 
age $[5,6]$. Furthermore, certain mental health-related behaviours such as anxiety [9, 10], loneliness [8], suicidal behaviour [11] and health risk behaviours including sexual risk behaviours $[8,12,13]$, and current smoking $[8,14]$ have been found to be associated with amphetamine and cannabis use. The literature has shown interpersonal factors within the school environment to be related to amphetamine and cannabis use: being bullied $[13,15]$, physical fighting and being physically attacked [15], school truancy [14-16], lack of peer support [14], having a greater number of friends $[17,18]$ and hunger [8]. In addition, parental attributes such as parental substance use $[9,19]$, lack of parental support and monitoring [14], lack of parental connectedness [9] and lack of maternal demandingness [8] have been shown to influence amphetamine and/or cannabis use among schoolgoing adolescents.

Within the Ghanaian context, no study has explored factors related to past-month cannabis and lifetime amphetamine use among school-going adolescents. Previous studies have predominantly focused on substance use (particularly tobacco and alcohol use) and its associated factors [6, 19, 20]. For example, Doku et al. [6] reported elevated levels of alcohol use and further indicated that alcohol use among school-going adolescents was associated with higher material affluence. Similarly, in their examination of the relationship between family dynamics and students' alcohol use, Asiseh et al. [19] revealed that parental alcohol use increased the odds of the adolescents' alcohol use irrespective of gender.

However, we are not well informed about the factors associated with cannabis and lifetime amphetamine use among school-going adolescents in Ghana. Additionally, since culture substantially influences human behaviour, the determinants of substance use as reported in developed Western countries (lack of parental support and monitoring, anxiety, loneliness, peer support, and sexual risk behaviours) $[10,14,16]$ may not be applicable to high school students in Ghana.

In order to adapt interventions for illicit drug use among school-going adolescents in Ghana, national population-based prevalence data on cannabis and amphetamine use are needed. Therefore, the purpose of this secondary analysis is to estimate the prevalence of cannabis and amphetamine use and its associated factors among school-going adolescents using a nationally representative school-based survey conducted in 2012. This study focused on past-month cannabis use and lifetime amphetamine use because regular cannabis use is more common among this population than regular amphetamine use [1-3]. The findings of this study could inform interventions that target high school students who may be at risk for regular cannabis and lifetime amphetamine use.

\section{Methods \\ Participants and procedure}

Data for this study were obtained from the Ghana Global School-based Student Health Survey (GSHS) conducted in 2012 [21]. This survey was conducted through a partnership between the World Health Organization (WHO), the Center for Disease Control and Prevention (CDC), Middle Tennessee State University and the Ghana Education Service (GES). The data were collected using a crosssectional survey design among WHO countries which were interested in examining the behavioural risk factors and protective factors in several domains of functioning among school-going adolescents. Data were collected through the use of close-ended structured questionnaires administered to the students. The GES's policies on ethics regarding the use of students in survey studies were adhered to in the data collection. Written informed consent was obtained from students aged 18 years and above, while parental consent was taken for students who were less than 18 years prior to their participation in the study. As stipulated by GSHS, participation in the study was voluntary, anonymous, and confidential. The response rate was $74 \%$.

\section{Sampling procedure}

Participants were sampled from selected junior (JHS) and senior high schools (SHS) in all 10 administrative regions of Ghana. A two-stage cluster sampling design was used to select 25 senior high schools to represent all 10 regions of Ghana. Selection of schools at the first stage of sampling was based on a probability proportional to size of enrollment. At the second stage, a random sampling technique was used to select the classes in each school. This allowed every student to have an equal chance of being selected for the study. Numerical weights were applied to each student record to enable generalization of results to the eligible population. The students were relatively equally split across the four senior high school grade levels.

\section{Measures}

The Ghana Global School-based Student Health Survey (GSHS) utilised a questionnaire that contained information on demographics, alcohol, tobacco, and other drug use, violence, and a range of other health-related behaviors [21, 22]. The Ghanaian version of the Global Student Health Survey was piloted and found to be culturally appropriate for use within Ghana [5]. The variables used in this study are described in Table 1. 
Table 1 Independent variables derivation from survey data

\begin{tabular}{|c|c|c|c|}
\hline Variable & Survey question & Original response options & Recoded \\
\hline Age & How old are you? & $11-18$ years (coded categorically) & $\mathrm{N} / \mathrm{A}$ \\
\hline Sex & What is your sex & $1=$ male; $0=$ female & $\mathrm{N} / \mathrm{A}$ \\
\hline Anxiety & $\begin{array}{l}\text { During the past } 12 \text { months, how often have you } \\
\text { been so worried about something that you } \\
\text { could not sleep at night? }\end{array}$ & $1=$ never to $5=$ always & $1-3=0$ and $4-5=1$ \\
\hline Loneliness & $\begin{array}{l}\text { During the past } 12 \text { months, how often have you } \\
\text { felt lonely? }\end{array}$ & $1=$ never to $5=$ always & $1-3=0$ and $4-5=1$ \\
\hline Suicidal Ideation & $\begin{array}{l}\text { During the past } 12 \text { months, did you ever seri- } \\
\text { ously consider attempting suicide? }\end{array}$ & Yes $=1 ; \mathrm{no}=2$ & Yes $=1$ and $n o=0$ \\
\hline Suicidal plan & $\begin{array}{l}\text { During the past } 12 \text { months, did you make a plan } \\
\text { about how you would attempt suicide? }\end{array}$ & Yes $=1 ;$ no $=2$ & Yes $=1$ and no $=0$ \\
\hline Suicidal attempt & $\begin{array}{l}\text { During the past } 12 \text { months, how many times, } \\
\text { did you actually attempted suicide }\end{array}$ & $1=0$ times to $5=6$ times or more & $1=0$ and $2-5=1$ \\
\hline School truancy & $\begin{array}{l}\text { During the past } 30 \text { days, how many days did } \\
\text { you miss classes or school without permis- } \\
\text { sion? }\end{array}$ & $1=0$ days to $5=10$ or more days & $1=0$ and $2-5=1$ \\
\hline Bullied & $\begin{array}{l}\text { During the past } 30 \text { days, how many days were } \\
\text { you bullied? }\end{array}$ & $1=0$ days to $7=$ all 30 days & $1-3=0$ and $4-7=1$ \\
\hline Physically attacked & $\begin{array}{l}\text { During the past } 12 \text { months, how many times } \\
\text { were you physically attack? }\end{array}$ & $1=0$ times to $8=12$ or more times & $1=0$ and $2-8=1$ \\
\hline In a physical fight & $\begin{array}{l}\text { During the past } 12 \text { months, how many times } \\
\text { were you in a physical fight? }\end{array}$ & $1=0$ times to $8=12$ or more times & $1=0$ and $2-8=1$ \\
\hline Hunger & $\begin{array}{l}\text { During the past } 30 \text { days, how often did you go } \\
\text { hungry because there was not enough food } \\
\text { in your home? }\end{array}$ & $1=$ never to $5=$ always & $1-3=0$ and $4-5=1$ \\
\hline Sexual risk behaviour & $\begin{array}{l}\text { During your life, with how many people have } \\
\text { you ever had sexual intercourse }\end{array}$ & $\begin{array}{l}1=\text { never had intercourse to } 7=6 \text { or more } \\
\text { people }\end{array}$ & $1=0$ and $2-7=1$ \\
\hline Close friends & How many close friends do you have? & $1=0$ friends to $4=3$ or more close friend & $1=0$ and $2-4=1$ \\
\hline Peer support & $\begin{array}{l}\text { During the past } 30 \text { days, how often were most } \\
\text { of the students in your class kind and helpful? }\end{array}$ & $1=$ never to $5=$ always & $1-3=0$ and $4-5=1$ \\
\hline Current smoking of cigarette & $\begin{array}{l}\text { During the past } 30 \text { days, how many days did } \\
\text { you smoke cigarette? }\end{array}$ & $1=0$ days to $7=$ all 30 days & $1=0$ and $2-7=1$ \\
\hline Parental tobacco use & $\begin{array}{l}\text { Which of your parents or guardian use any form } \\
\text { of tobacco? }\end{array}$ & $1=$ never to $4=$ both & $1=0$ and $2-4=1$ \\
\hline Parental monitoring & $\begin{array}{l}\text { During the past } 30 \text { days, how often did your } \\
\text { parents or guardians check to see if your } \\
\text { homework was done? }\end{array}$ & $1=$ never to $5=$ always & $1-3=0$ and $4-5=1$ \\
\hline Parental understanding & $\begin{array}{l}\text { During the past } 30 \text { days, how often did your } \\
\text { parents or guardians understand your prob- } \\
\text { lems and worries? }\end{array}$ & $1=$ never to $5=$ always & $1-3=0$ and $4-5=1$ \\
\hline Parental bonding & $\begin{array}{l}\text { During the past } 30 \text { days, how often did your } \\
\text { parents or guardians really know what you } \\
\text { were doing you're your free time? }\end{array}$ & $1=$ never to $5=$ always & $1-3=0$ and $4-5=1$ \\
\hline Parental intrusion of privacy & $\begin{array}{l}\text { During the past } 30 \text { days, how often did your } \\
\text { parents or guardians go through your things } \\
\text { without your approval? }\end{array}$ & $1=$ never to $5=$ always & $1-3=0$ and $4-5=1$ \\
\hline Cannabis use & $\begin{array}{l}\text { During the past } 30 \text { days, how many times have } \\
\text { you used marijuana (also called weed, Jah, } \\
\text { Indian hemp, ahabammmono, and ganja)?" }\end{array}$ & $1=0$ days to $5=$ All 30 days & $1=0$ and $2-5=1$ \\
\hline Amphetamine & $\begin{array}{l}\text { During your life, how many times have you used } \\
\text { amphetamine or methamphetamine (also } \\
\text { called ice or yellow) }\end{array}$ & $1=0$ times to $5=20$ or more times & $1=0$ and $2-5=1$ \\
\hline
\end{tabular}

\section{Data analysis}

Sample weights were applied in all analyses to reduce bias from non-response, improve generalisability to the population, and further to reduce bias on the differing pattern of non-response. All variables were re-coded on a dichotomous scale as in other existing GSHS studies [11, 
$12,19,20]$. The primary analyses were performed in two steps to determine factors most strongly associated with cannabis and lifetime amphetamine use in adolescents. First, bivariate analyses using the Chi-square $\left(\mathrm{x}^{2}\right)$ test were used to examine possible associations between the explanatory variables and past-month cannabis and lifetime amphetamine use. In the second step, Multinomial logistic regression analyses were conducted to examine the independent predictors of substance use. The results from the regression analyses are presented as odds ratios (OR) with 95\% confidence intervals (CI). Statistical significance was defined as two-tailed $p$-value $<0.05$ in all analyses. The Statistical Package for the Social Sciences (SPSS) version 23.0 was used to conduct data analyses.

\section{Results}

\section{Sample characteristics}

A total of 3632 school-going adolescents aged 11-19 (mean $=15.1$ years; $S D=1.4$ ) participated in the study. This sample included 1932 (53.2\%) males and $1662(45.8 \%)$ females. Gender data were missing for 38 participants (1\%). About a third of the students, $(\mathrm{n}=1062 ; 32.5 \%)$ were aged 18 years or older. Students aged 14 years and below comprised $24.4 \%$ of the sample, those aged 15 years constituted $13.8 \%$, while those aged 16 years and 17 years constituted $12.2 \%$ and $16.9 \%$ of the sample respectively. Over half of the students (54.5\%) were in senior high schools while the remaining $45.5 \%$ were in junior high school. Past-month cannabis use was $5.3 \%$ and lifetime amphetamine use was $7.1 \%$ among students.

\section{The relationship between cannabis and amphetamine use} and their associated factors

The bivariate analysis of the factors associated with cannabis and amphetamine use among school-going adolescents in Ghana are presented in Table 2. Gender and age were not associated with either past-month cannabis use or lifetime amphetamine use. Mental health variables such as loneliness, and suicidal behaviour (i.e. ideation, plan, and attempt) were related to cannabis use but only loneliness, suicidal plan, and attempt were related to amphetamine use. Personal attributes such as truancy and cigarette smoking were independently associated with both past-month cannabis use and lifetime amphetamine use. A higher number of close friends was only associated with past-month cannabis use.

School environmental factors such as bullying victimisation and being physically attacked were associated with lifetime amphetamine use whilst bullying victimisation and hunger were related to past-month cannabis use. Parental substance use was related to both past-month cannabis use, and lifetime amphetamine use, but parental understanding of adolescents was only associated with past-month cannabis use.

\section{Predictors of cannabis and amphetamine use among school-going adolescents}

The predictors of both past-month cannabis use, and lifetime amphetamine use are presented in Table 3. In multivariate analysis, after controlling for other variables, school truancy $(\mathrm{OR}=3.34 ; 95 \% \mathrm{CI}=1.88-5.92 ; p<0.001)$ and current smoking $(\mathrm{OR}=12.48 ; 95 \% \mathrm{CI}=6.48-24.02$; $p<0.001)$ were associated with past-month cannabis use. A greater number of close friends was positively associated with only past-month cannabis use $(\mathrm{OR}=2.37$; $95 \%$ $\mathrm{CI}=1.19-4.71 ; p<0.05)$. The results further showed in adjusted analysis that school truancy $(\mathrm{OR}=1.74 ; 95 \%$ $\mathrm{CI}=1.13-2.68 ; p<0.05)$, current smoking $(\mathrm{OR}=4.74$; 95\% $\mathrm{CI}=2.50-9.00 ; p<0.001)$, school environment factors such as bullying victimisation $(\mathrm{OR}=2.09 ; 95 \%$ $\mathrm{CI}=1.27-3.43 ; \quad p<0.01)$ and having been attacked $(\mathrm{OR}=2.16 ; 95 \% \mathrm{CI}=1.36-3.45 ; p<0.01)$, as well as parental substance use $(\mathrm{OR}=2.45 ; 95 \% \mathrm{CI}=1.45-4.13$; $p<0.01)$ were associated with lifetime amphetamine use.

\section{Discussion}

The aim of this study was to examine the prevalence of past-month cannabis use and lifetime amphetamine use and to determine associated factors among schoolgoing adolescents in Ghana. A prevalence rate of 5.3\% and $7.1 \%$ were found for past-month cannabis use and lifetime amphetamine use respectively. The high prevalence of past-month cannabis use in this study is lower to the reported rate of $7.2 \%$ found among adolescents in 2012 [6] but seems to indicate an increase compared to an earlier study that reported a prevalence rate of $2.6 \%$ [7]. The prevalence rate of $5.3 \%$ reported in this study is similar to a UNODC report [1] indicating that adolescent past 30-day cannabis use was also low in Nigeria (4.4\%) and Morocco (4.0\%). A recent study also reported past 30 -day cannabis use prevalence rates of $5.3 \%, 4.6 \%$ and $4.3 \%$ for Namibia, Swaziland, and Mauritius respectively [8]. In this study, the prevalence rate for lifetime amphetamine use was $7.1 \%$, which is comparable to what has been reported among school-going adolescents in previous studies within sub-Saharan Africa [4, 9, 23]. The high prevalence rate for lifetime amphetamine use as found in this study is similar to a UNODC report which found a past year amphetamine prevalence rate of $7.6 \%$ among students in Ghana [2]. The current trend for cannabis use in the sub-Saharan Africa region is lower than the rates reported in this study.

The results further showed that age and gender were not significantly associated with either past-month cannabis use and lifetime amphetamine use. These results 
Table 2 Bivariate analysis of the factors associated with cannabis and amphetamine use among school-going adolescents in Ghana

\begin{tabular}{|c|c|c|c|c|c|c|}
\hline \multirow[t]{2}{*}{ Variables } & \multicolumn{3}{|c|}{$\begin{array}{l}\text { Past-month cannabis use } \\
N=184\end{array}$} & \multicolumn{3}{|c|}{$\begin{array}{l}\text { Lifetime amphetamine use } \\
N=238\end{array}$} \\
\hline & No (\%) & Yes (\%) & $p$-value & No (\%) & Yes (\%) & $p$-value \\
\hline \multicolumn{7}{|l|}{ Demographics } \\
\hline Gender & & & 0.540 & & & 0.450 \\
\hline Male & 95.1 & 4.9 & & 93.3 & 6.7 & \\
\hline Female & 94.6 & 5.4 & & 92.6 & 7.4 & \\
\hline Age in years & & & 0.055 & & & 0.120 \\
\hline $11-17$ years & 94.2 & 5.8 & & 92.4 & 7.6 & \\
\hline 18 years and above & 95.8 & 4.2 & & 93.9 & 6.1 & \\
\hline \multicolumn{7}{|l|}{ Mental health problems } \\
\hline Anxiety & & & 0.068 & & & 0.052 \\
\hline Yes & 91.7 & 8.3 & & 87.6 & 12.4 & \\
\hline No & 95.3 & 4.7 & & 93.8 & 6.2 & \\
\hline Loneliness & & & 0.032 & & & 0.018 \\
\hline Yes & 91.5 & 8.5 & & 88.7 & 11.3 & \\
\hline No & 95.4 & 4.6 & & 93.7 & 6.3 & \\
\hline Suicidal ideation & & & 0.011 & & & 0.091 \\
\hline Yes & 87.9 & 12.1 & & 85.5 & 14.5 & \\
\hline No & 96.6 & 3.4 & & 95.0 & 5.0 & \\
\hline Suicidal plan & & & 0.019 & & & 0.049 \\
\hline Yes & 90.3 & 9.7 & & 88.0 & 12.0 & \\
\hline No & 97.1 & 2.9 & & 95.3 & 4.7 & \\
\hline Suicidal attempt & & & 0.028 & & & 0.012 \\
\hline Yes & 85.5 & 14.5 & & 82.3 & 17.7 & \\
\hline No & 97.8 & 2.2 & & 96.3 & 3.7 & \\
\hline \multicolumn{7}{|l|}{ Personal attributes } \\
\hline Truancy & & & $<0.001$ & & & $<0.001$ \\
\hline Yes & 89.0 & 11.0 & & 87.6 & 12.4 & \\
\hline No & 98.2 & 1.8 & & 96.0 & 4.0 & \\
\hline Smoked cigarette & & & $<0.001$ & & & 0.003 \\
\hline Yes & 54.9 & 45.1 & & 56.2 & 43.8 & \\
\hline No & 97.3 & 2.7 & & 95.5 & 4.5 & \\
\hline Close friends & & & 0.021 & & & 0.610 \\
\hline Yes & 94.9 & 5.1 & & 92.9 & 7.1 & \\
\hline No & 95.5 & 4.5 & & 93.7 & 6.3 & \\
\hline Peer support & & & 0.680 & & & 0.720 \\
\hline Yes & 94.6 & 5.4 & & 92.7 & 7.3 & \\
\hline No & 94.9 & 5.1 & & 93.0 & 7.0 & \\
\hline Sexual risk behaviour & & & 0.061 & & & 0.065 \\
\hline Yes & 88.0 & 12.0 & & 86.1 & 13.9 & \\
\hline No & 96.6 & 3.4 & & 94.8 & 5.2 & \\
\hline \multicolumn{7}{|c|}{ School environmental factors } \\
\hline Bullying victimization & & & 0.044 & & & $<0.001$ \\
\hline Yes & 91.7 & 8.3 & & 89.3 & 10.7 & \\
\hline No & 98.0 & 2.0 & & 96.7 & 3.3 & \\
\hline Physically attacked & & & 0.060 & & & $<0.001$ \\
\hline Yes & 90.4 & 9.6 & & 87.6 & 12.4 & \\
\hline No & 97.8 & 2.2 & & 96.5 & 3.5 & \\
\hline
\end{tabular}


Table 2 (continued)

\begin{tabular}{|c|c|c|c|c|c|c|}
\hline \multirow[t]{2}{*}{ Variables } & \multicolumn{3}{|c|}{$\begin{array}{l}\text { Past-month cannabis use } \\
N=184\end{array}$} & \multicolumn{3}{|c|}{$\begin{array}{l}\text { Lifetime amphetamine use } \\
N=238\end{array}$} \\
\hline & No (\%) & Yes (\%) & $p$-value & No (\%) & Yes (\%) & $p$-value \\
\hline Physical fight & & & 0.058 & & & 0.049 \\
\hline Yes & 90.7 & 9.3 & & 88.6 & 11.4 & \\
\hline No & 97.1 & 2.9 & & 95.3 & 4.7 & \\
\hline Hunger & & & 0.030 & & & 0.080 \\
\hline Yes & 90.9 & 9.1 & & 88.6 & 11.4 & \\
\hline No & 95.4 & 4.6 & & 93.6 & 6.4 & \\
\hline \multicolumn{7}{|l|}{ Parental attributes } \\
\hline Parental substance use & & & 0.018 & & & $<0.001$ \\
\hline Yes & 81.7 & 18.3 & & 79.6 & 20.4 & \\
\hline No & 96.5 & 3.5 & & 94.8 & 5.2 & \\
\hline Parental monitoring & & & 0.070 & & & 0.270 \\
\hline Yes & 95.6 & 4.4 & & 92.3 & 7.7 & \\
\hline No & 94.3 & 5.7 & & 93.3 & 6.7 & \\
\hline Parental understanding & & & 0.010 & & & 0.620 \\
\hline Yes & 96.1 & 3.9 & & 92.7 & 7.3 & \\
\hline No & 93.9 & 6.1 & & 93.2 & 6.8 & \\
\hline Parental bonding & & & 0.110 & & & 0.890 \\
\hline Yes & 95.6 & 4.4 & & 93.2 & 6.8 & \\
\hline No & 94.3 & 5.7 & & 93.0 & 7.0 & \\
\hline Parental intrusion of privacy & & & 0.060 & & & 0.090 \\
\hline Yes & 95.4 & 4.6 & & 93.6 & 6.4 & \\
\hline No & 93.9 & 6.1 & & 92.1 & 7.9 & \\
\hline
\end{tabular}

contradict previous studies that have established such associations [5, 8, 13]. Mental health variables such as anxiety, loneliness and suicidality did not predict either past-month cannabis or lifetime amphetamine use. These results contradict previous studies that have established such associations [8-11].

In this study, parental substance use was found to be associated with lifetime amphetamine use. This means that school-going adolescents who reported parental substance use were more likely to engage in substance use. This result confirms evidence from previous studies [9, 19] which indicate that parental engagement in a behavior is a huge predictor of offspring engaging in the same behaviour. Determining the association between parental substance use and adolescent substance use later in life is not straightforward [24]. This relationship between familial substance use and the likelihood of substance use in adolescence has been discussed through three (3) main pathways. One school of thought argues that family members with substance use problems may serve as behavioural models for young people living in the same household [19]. The second perspective indicates that family members living with problematic substance use may also store drugs and/or alcohol in the house making these substances more readily available to young people [25]. The third pathway is that substance use has a significant genetic component which explains why children of parents who use substances also use substances [26]. In Ghana, parental substance use may serve as a behavioural model which young people living in the same household imitate. Thus, their behaviour may send a message to these adolescents that it is acceptable for them to do the same.

The results further showed that school-related variables such as bullying victimisation and being physically attacked were associated with lifetime amphetamine use. The relationship between being physically attacked and lifetime amphetamine use is exceedingly complex and may be moderated by a host of individual and environmental factors. It is, however, possible that interpersonal level risk factors within the school environment may have played a role in this association, as indicated by previous studies [13, 15]. Additionally, the relationship between bullying victimisation and lifetime amphetamine use, could possibly be due to prior bullying victimisation that may predispose an adolescent to use amphetamine 
Table 3 Association with cannabis and amphetamine use among school-going adolescents in Ghana

\begin{tabular}{llll}
\hline Variables & $\begin{array}{l}\text { Past-month } \\
\text { cannabis use }\end{array}$ & $\begin{array}{l}\text { Lifetime } \\
\text { amphetamine } \\
\text { use }\end{array}$ \\
\cline { 2 - 2 } $95 \% \mathrm{Cl}$ & AOR $95 \% \mathrm{Cl}$ \\
\hline
\end{tabular}

\begin{tabular}{|c|c|c|c|c|}
\hline \multicolumn{5}{|l|}{ Demographics } \\
\hline \multicolumn{5}{|l|}{ Age in years } \\
\hline $11-17$ years & 1 & - & 1 & - \\
\hline 18 years and above & 0.91 & $0.51-1.62$ & 0.98 & $0.62-1.55$ \\
\hline Sex (male) & 0.74 & $0.43-1.28$ & 1.07 & \\
\hline \multicolumn{5}{|l|}{ Mental health problems } \\
\hline Anxiety & 0.71 & $0.34-1.50$ & 1.21 & $0.71-2.07$ \\
\hline Loneliness & 0.99 & $0.51-1.91$ & 1.08 & $0.64-1.81$ \\
\hline Suicidal ideation & 1.84 & $0.97-3.50$ & 1.51 & $0.88-2.60$ \\
\hline Suicidal plan & 1.43 & $0.75-2.73$ & 1.18 & $0.68-2.03$ \\
\hline Suicidal attempt & 1.40 & $0.70-2.80$ & 1.44 & $0.81-0.59$ \\
\hline \multicolumn{5}{|l|}{ Personal attributes } \\
\hline School truancy & 3.34 & $1.88-5.92^{* * *}$ & 1.74 & $1.13-2.68^{*}$ \\
\hline Smoked cigarette & 12.48 & $6.48-24.02^{* * *}$ & 4.74 & $2.50-9.00 * * *$ \\
\hline Close friends & 2.37 & $1.20-4.71^{*}$ & 1.43 & $0.79-2.60$ \\
\hline Peer support & 1.50 & $0.83-2.72$ & 1.31 & $0.83-2.07$ \\
\hline Sexual risk behaviour & 1.71 & $0.92-3.20$ & 1.59 & $0.93-2.71$ \\
\hline \multicolumn{5}{|c|}{ School environmental factors } \\
\hline Bullying victimisation & 1.65 & $0.87-3.13$ & 2.09 & $1.27-3.43^{* *}$ \\
\hline Physically attacked & 1.61 & $0.89-2.93$ & 2.16 & $1.36-3.45^{* *}$ \\
\hline Physical fight & 1.54 & $0.84-2.82$ & 0.94 & $0.58-1.52$ \\
\hline Hunger & 0.99 & $0.49-1.99$ & 1.35 & $0.78-2.33$ \\
\hline \multicolumn{5}{|l|}{ Parental attributes } \\
\hline Parental substance use & 1.88 & $0.97-3.64$ & 2.45 & $1.45-4.13^{* *}$ \\
\hline Parental monitoring & 0.90 & $0.50-1.79$ & 1.31 & $0.82-2.11$ \\
\hline Parental understanding & 0.75 & $0.39-1.41$ & 1.58 & $0.99-2.51$ \\
\hline Parental bonding & 0.91 & $0.48-1.74$ & 1.07 & $0.67-1.73$ \\
\hline $\begin{array}{l}\text { Parental intrusion of } \\
\text { privacy }\end{array}$ & 1.04 & $0.60-1.80$ & 1.09 & $0.71-1.68$ \\
\hline
\end{tabular}

AOR adjusted odds ratio for all factors which appear in table, $\mathrm{Cl}$ confidence interval

${ }^{*} p<0.05 ;{ }^{* *} p<0.01 ;{ }^{* * *} p<0.001$

as a maladaptive coping strategy. This finding may also provide some support for the stress coping and selfmedication model where recipients of peer victimisation, particularly those with poor coping strategies or self-regulatory processes may use substances as a way to deal with the pains associated with the victimisation experience [27-29]. With no anti-bullying policy in place within Ghanaian schools, in addition to the high prevalence of bullying reported among adolescents [30], this finding is a wake-up call for the Ghana Education Service (GES). The GES should consider these pathways in policy considerations for staff gatekeeping training programmes to address bullying victimisation.

Previous studies have reported that having more friends is protective against substance use $[17,18]$. However, the inverse was found in the present study where the odds of cannabis use increased with a higher number of close friends. It has been reported that friendship provides a channel for adolescents to learn new social skills and subsequently experience positive developmental outcomes. However, it is possible that within the context of this study, having several friends led to the development of negative peer risk behaviours including substance use. Plausibly, such negative peer relationships may be associated with heightened health risk behaviours such as cannabis use, and thus underscore the need to emphasize supportive relationships between peers and develop strategies to promote positive peer support.

The findings also reveal that school truancy was a risk factor for both past-month cannabis use and lifetime amphetamine use. Consistent with the results of this study, several studies have established a relationship between school truancy and illicit substance use (i.e. cannabis and amphetamine use) [14-16, 19]. The relationship between truancy and substance use may be attributed to the weakened sense of school belonging among school-going adolescents. Schools are key social institutions which play an important role in constraining problem behaviours among adolescents [31]. However, since adolescence is also a time of increasing independence and searching for autonomy [32], reduced school engagement may also expose young people to healthcompromising behaviours including substance use. It should be noted, though, that while truancy was associated with substance use, not all truants use substances [33].

Furthermore, school-going adolescents who smoked cigarettes were 12.5 and 4.8 times more likely to be pastmonth cannabis users and lifetime amphetamine users respectively. The presence of clustering of cigarette use with other illicit substance use including cannabis use has been reported in previous studies $[8,14,34]$. These findings underscore the need for the development of polydrug use interventions among school-going adolescents.

\section{Limitations of the study}

This study has some limitations. Firstly, the key outcome variables, amphetamine and cannabis use, were self-reported. Self-report may be confounded by systematic and social desirability biases. Secondly, the majority of the measures used were single item measures which only allows narrow assessment of these variables. Thirdly, results are based on a cross-sectional database, thus limiting our ability to establish causality. 
Longitudinal studies concerning amphetamine and cannabis use among school-going adolescents are needed. Finally, the study only included adolescents attending school; out of school, 11-18 year-olds were not included. Therefore, findings are not representative of all adolescents in this age group. Despite these limitations, this is one of the first cross-sectional studies to have used nationally representative data to explore the prevalence of cannabis and amphetamine use and their associated factors among school-going adolescents.

\section{Conclusion}

This study was conducted to examine the prevalence and factors associated with amphetamine and cannabis use among school-going adolescents in Ghana. Although the prevalence of amphetamine use in this adolescent population in Ghana may not be as high as in some highincome countries, this study found a high prevalence of cannabis use. This study identified a number of risk factors for both cannabis and amphetamine use including truancy and cigarette smoking. While parental substance use, bullying victimisation and having been physically attacked were risk factors for amphetamine use, having a greater number of close friends was a risk factor for cannabis use. School-based health programmes should be developed which take the risk factors associated with cannabis and amphetamine use among school-going adolescents in Ghana into consideration.

\section{Acknowledgements \\ The author extends his sincere appreciation to the students, teachers, Ghana Education Service and the Ministry of Health for their participation and assis- tance in the Global School-based Student Health Survey. I am also grateful to World Health Organization (Geneva, Switzerland) and the Centres for Disease Control and Prevention (Atlanta, USA) for making the data freely available for this study.}

\section{Authors' contributions}

KOA designed the study, analysed the data, drafted the manuscript. The author read and approved the final manuscript.

\section{Funding}

No funding received for this study.

\section{Availability of data and materials}

Data is freely available online from Ghana Global School-based Student Health Survey (GSHS).

\section{Ethics approval and consent to participate}

National Ethics Committees approved the study protocol and informed consent was obtained from the students, parents and/or school officials (Center for Disease Control, 2017).

\section{Consent for publication}

Not applicable.

\section{Competing interests}

The author declares no competing interests.

\section{Author details}

${ }^{1}$ Department of Psychology, University of Ghana, P. O. Box LG 84, Legon, Accra, Ghana. ${ }^{2}$ Department of Psychology, University of the Free State, Bloemfontein, South Africa. ${ }^{3}$ Institute for Psychosocial Research on Child and Adolescent Wellbeing (IPRECAW), Accra, Ghana.

Received: 22 October 2018 Accepted: 22 August 2019

Published online: 29 August 2019

\section{References}

1. United Nations Office on Drugs and Crime (UNODC). World drug report 2016. Sales No. E.16.XI.7, 2017. New York: United Nations Publication.

2. World Health Organization (WHO). Other psychoactive substances. 2017. http://www.who.int/substanceabuse/facts/psychoactives/en/. Accessed 05 May 2018.

3. United Nations Office on Drugs and Crime (UNODC). World drug report 2016. Sales No. E.16.XI.7. 2016, New York: United Nations Publication; 2016.

4. Shisana O, Rehle T, Simbayi LC, Zuma K, Jooste S, Zungu N, Labadarios D, Onoya D. South African national HIV prevalence, incidence and behaviour survey, 2014. Cape Town: HSRC Press; 2012.

5. Owusu A. Ghana Country report on the global school-based health survey (GSHS). Center for Disease Control and Prevention (CDC): Atlanta, CA; 2008.

6. Doku D. Substance use and risky sexual behaviours among sexually experienced Ghanaian youth. BMC Public Health. 2012;12:571. https:// doi.org/10.1186/1471-2458-12-571.

7. Adu-Mireku S. The prevalence of alcohol, cigarette, and marijuana use among Ghanaian senior secondary students in an urban setting. J Ethn Subst Abuse. 2003;2:53-65. https://doi.org/10.1300/J233v02n01_05.

8. Peltzer K Pengpid S. Cannabis and amphetamine use and associated factors among school-going adolescents in nine African countries. J Child Adolesc Subst Abuse. 2018:27:112-8. https://doi.org/10.1080/10678 28X.2017.1420512.

9. Kpozehouen A, Ahanhanzo YG, Paraıso MN, Munezero F, Saizonou JZ, Makoutode M, Ouedraogo LT. Factors associated with psychoactive substance use among Beninese adolescents. Sante Publique. 2015;27:87180. https://doi.org/10.3917/spub.156.0871

10. Savage JE, Kaprio J, Korhonen T, Pulkkinen L, Rose RJ, Verhulst B, Dick DM. The effects of social anxiety on alcohol and cigarette use across adolescence: results from a longitudinal twin study in Finland. Psychol Addict Behav. 2016;30:462-74. https://doi.org/10.1037/adb0000183.

11. Oppong Asante K, Kugbey N, Osafo J, Quarshie ENB, Sarfo JO. The prevalence and correlates of suicidal behaviours (ideation, plan and attempt) among adolescents in senior high schools in Ghana. SSM-Popul Health. 2017;3:427-34. https://doi.org/10.1016/j.ssmph.2017.05.005.

12. Kugbey N, Ayanore MA, Amu H, Oppong Asante K, Adam A. International note: analysis of risk and protective factors for risky sexual behaviours among school-aged adolescents. J Adolesc. 2018;68:66-9. https://doi. org/10.1016/j.adolescence.2018.06.013.

13. Siziya S, Muula AS, Besa C, Babaniyi O, Songolo P, Kankiza N, Rudatsikira E. Cannabis use and its socio-demographic correlates among in-school adolescents in Zambia. Ital J Pediatr. 2013;39:13. https://doi. org/10.1186/1824-7288-39-13.

14. Yusoff F, Sahril N, Rasidi NM, Zaki NA, Muhamad N, Ahmad N. Illicit drug use among school-going adolescents in Malaysia. Asia Pac J Public Health. 2014;26:100S-7S. https://doi.org/10.1177/1010539514542425.

15. Ohene SA, Johnson K, Atunah-Jay S, Owusu A, Borowsky IW. Sexual and physical violence victimization among senior high school students in Ghana: risk and protective factors. Soc Sci Med. 2015;146:266-75. https:// doi.org/10.1016/.socscimed.2015.10.019.

16. Goldberg-Looney LD, Sánchez-SanSegundo M, Ferrer-Cascales R, Albaladejo-Blazquez N, Perrin PB. Adolescent alcohol use in Spain: connections with friends, school, and other delinquent behaviors. Front Psychol. 2016;7:269-96. https://doi.org/10.3389/fpsyg.2016.00269.

17. Nash SG, McQueen A, Bray JH. Pathways to adolescent alcohol use: family environment, peer influence, and parental expectations. J Adolesc Health. 2005;37:19-28. https://doi.org/10.1016/j.jadohealth.2004.06.004 
18. Peltzer K, Pengpid S, Tepirou C. Associations of alcohol use with mental health and alcohol exposure among school-going students in Cambodia. Nagoya J Med Sci. 2016;78:415-22. https://doi.org/10.18999/nagjm s.78.4.415.

19. Asiseh F, Owusu A, Quaicoe O. An analysis of family dynamics on high school adolescent risky behaviors in Ghana. J Child Adolesc Subst Abuse. 2017;26:425-31. https://doi.org/10.1080/1067828X.2017.1322019.

20. Asante KO, Kugbey N. Alcohol use by school-going adolescents in Ghana: prevalence and correlates. Ment Health Prev. 2019;16:75-82. https://doi. org/10.1016/j.mhp.2019.01.009.

21. World Health Organization (WHO). Global School-based Student Health Survey (GSHS). 2014. http://www.who.int/chp/gshs/en/. Accessed 20 June 2017.

22. World Health Organization (WHO). Global school-based student health survey (GSHS) purpose and methodology. 2014. http://www.who.int/ chp/gshs/methodology/en/. Accessed 20 June 2017.

23. Zarrouq B, Bendaou B, El Asri A, Achour S, Rammouz I, Aalouane R, El Rhazi K. Psychoactive substances use and associated factors among middle and high school students in the North Center of Morocco: a crosssectional questionnaire survey. BMC Public Health. 2016;16:468. https:// doi.org/10.1186/s12889-016-3143-5.

24. Kliewer W, Murrelle L. Risk and protective factors for adolescent substance use: findings from a study in selected Central American countries. J Adolesc Health. 2007:40:448-55. https://doi.org/10.1016/j.jadohealth .2006.11.148

25. Kabiru CW, Beguy D, Crichton J, Ezeh AC. Self-reported drunkenness among adolescents in four sub-Saharan African countries: associations with adverse childhood experiences. Child Adolesc Psychiatry Ment Health. 2001;4:17. https://doi.org/10.1186/1753-2000-4-17.

26. Kendler KS, Chen X, Dick D, Maes H, Gillespie N, Neale MC, Riley B. Recent advances in the genetic epidemiology and molecular genetics of substance use disorders. Nat Neurosci. 2012;15:181-9. https://doi. org/10.1038/nn.3018.
27. Maniglio R. Severe mental illness and criminal victimization: a systematic review. Acta Psychiatr Scand. 2009;119:180-91. https://doi.org/10.111 1/j.1600-0447.2008.01300.x

28. Maniglio R. Association between peer victimization in adolescence and cannabis use: a systematic review. Aggress Violent Behav. 2015;25:252-8. https://doi.org/10.1016/j.avb.2015.09.002.

29. Morojele NK, Brook JS. Substance use and multiple victimisation among adolescents in South Africa. Addict Behav. 2006;31:1163-76. https://doi. org/10.1016/j.addbeh.2005.09.009.

30. Owusu A, Hart P, Oliver B, Kang M. The association between bullying and psychological health among senior high school students in Ghana, West Africa. J Sch Health. 2011;81:231-8. https://doi.org/10.111 1/j.1746-1561.2011.00590.x.

31. Henry KL, Thornberry TP. Truancy and escalation of substance use during adolescence. J Stud Alcohol Drugs. 2010;71:115-24. https://doi. org/10.15288/jsad.2010.71.115.

32. Sumter SR, Bokhorst CL, Steinberg L, Westenberg PM. The developmental pattern of resistance to peer influence in adolescence: will the teenager ever be able to resist? J Adolesc. 2009;32:1009-21. https://doi. org/10.1016/j.adolescence.2008.08.010.

33. Hallfors D, Vevea JL, Iritani B, Cho H, Khatapoush S, Saxe L. Truancy, grade point average, and sexual activity: a meta-analysis of risk indicators for youth substance use. J Sch Health. 2002;72:205-11. https://doi. org/10.1111/j.1746-1561.2002.tb06548.x.

34. Agrawal A, Budney AJ, Lynskey MT. The co-occurring use and misuse of cannabis and tobacco: a review. Addiction. 2012;107:1221-33. https://doi org/10.1111/j.1360-0443.2012.03837.x.

\section{Publisher's Note}

Springer Nature remains neutral with regard to jurisdictional claims in published maps and institutional affiliations.
Ready to submit your research? Choose BMC and benefit from:

- fast, convenient online submission

- thorough peer review by experienced researchers in your field

- rapid publication on acceptance

- support for research data, including large and complex data types

- gold Open Access which fosters wider collaboration and increased citations

- maximum visibility for your research: over 100M website views per year

At BMC, research is always in progress.

Learn more biomedcentral.com/submissions 